\title{
A multi-approach and multi-scale study on water quantity and quality changes in the Tapajós River basin, Amazon
}

\author{
Rodolfo Luiz Bezerra Nóbrega ${ }^{1, a}$, Gabriele Lamparter ${ }^{1}$, Harold Hughes ${ }^{1}$, Alphonce Chenjerayi Guzha ${ }^{2}$, \\ Ricardo Santos Silva Amorim ${ }^{3}$, and Gerhard Gerold ${ }^{1}$ \\ ${ }^{1}$ Department of Physical Geography, Faculty of Geoscience and Geography, \\ University of Göttingen, Göttingen, Germany \\ ${ }^{2}$ USDA Forest Service, International Programs, c/o CIFOR, World Agroforestry Center, Nairobi, Kenya \\ ${ }^{3}$ Department of Soil and Agricultural Engineering, Federal University of Mato Grosso, Cuiabá, MT, Brazil \\ ${ }^{a}$ now at: Department of Geography \& Environmental Science, University of Reading, Reading, UK
}

Correspondence: Rodolfo Luiz Bezerra Nóbrega (r.nobrega@ reading.ac.uk)

Received: 7 June 2017 - Revised: 6 November 2017 - Accepted: 15 November 2017 - Published: 16 April 2018

\begin{abstract}
We analyzed changes in water quantity and quality at different spatial scales within the Tapajós River basin (Amazon) based on experimental fieldwork, hydrological modelling, and statistical time-trend analysis. At a small scale, we compared the river discharge $(Q)$ and suspended-sediment concentrations (SSC) of two adjacent micro-catchments $\left(<1 \mathrm{~km}^{2}\right)$ with similar characteristics but contrasting land uses (forest vs. pasture) using empirical data from field measurements. At an intermediary scale, we simulated the hydrological responses of a sub-basin of the Tapajós (Jamanxim River basin, $37400 \mathrm{~km}^{2}$ ), using a hydrological model (SWAT) and land-use change scenario in order to quantify the changes in the water balance components due to deforestation. At the Tapajós' River basin scale, we investigated trends in $Q$, sediments, hydrochemistry, and geochemistry in the river using available data from the HYBAM Observation Service. The results in the micro-catchments showed a higher runoff coefficient in the pasture (0.67) than in the forest catchment (0.28). At this scale, the SSC were also significantly greater during stormflows in the pasture than in the forest catchment. At the Jamanxim watershed scale, the hydrological modelling results showed a $2 \%$ increase in $Q$ and a $5 \%$ reduction of baseflow contribution to total $Q$ after a conversion of $22 \%$ of forest to pasture. In the Tapajós River, however, trend analysis did not show any significant trend in discharge and sediment concentration. However, we found upward trends in dissolved organic carbon and $\mathrm{NO}_{3}^{-}$over the last 20 years. Although the magnitude of anthropogenic impact has shown be scale-dependent, we were able to find changes in the Tapajós River basin in streamflow, sediment concentration, and water quality across all studied scales.
\end{abstract}

\section{Introduction}

Southern Amazonia was the first region of Brazil's Amazon area to be exposed to intensive conversion to agricultural lands (Fearnside, 2016). The Tapajós River, an important tributary of the Amazon River, lost in this basin ca. $30 \%$ of forest cover (ca. $500000 \mathrm{~km}^{2}$ ) by 2016 , mainly due to the establishment of agro-industrial farms. The forest loss in this river basin is projected to reach approximately $65 \%$ by 2050 (Soares-Filho et al., 2006).
The understanding of small areas is essential to propose solutions to maintain tropical forest services, such as water and nutrient cycling, in the Amazon (Vedovato et al., 2016). These areas can be well assessed by experimental catchment studies. For example, Bleich et al. (2016) studied 10 small pristine streams in the Tapajós River basin and argue that in case measures of conservation of small catchments are not taken, environmental impacts on regional streams in South Amazonia are expected to increase. Impacts at regional scales have been the concern of the scientific community with regards to the role of tropical forests in the 
global climate systems, especially the effects of the Amazon deforestation in large scales (Ometto et al., 2011). Lima et al. (2014) argue that large-scale deforestation triggers complex non-linear interactions between the atmosphere and biosphere, which may impair important ecosystem services such as water for agriculture and hydroelectric power generation.

Although it has been reported that deforestation leads to changes in the water cycle in this region (Davidson et al., 2012), the effects of forest clearing on the concentrations of suspended and dissolved materials that are usually seen in small streams are difficult to be detected in larger streams and rivers (Thomas et al., 2004). However, the chemistry of the large rivers in the Amazon that remained relatively unaltered until 2000 was compromised because of the upcoming growing of area occupied by pastures (Neill et al., 2001). Additionally, analyses of land-use change impacts that were usually limited to small plots or experimental catchments are now possible to be applied to larger scales, such as river basins, due to recent improvements in data collection, archiving and distribution (Eshleman, 2004). New evidence shows that the conversion of forest to pasture is manifested in systematic changes in the hydro-climatology cycle with increase in river discharge in large catchments in the Amazon (SouzaFilho et al., 2016).

In this study, we examined the impact of the land-use change on the streamflow and water quality of the Tapajós River basin using different spatial scales and approaches. Our objective is to identify what signatures from the landuse change are possible to observe within and across these scales.

\section{Area of study}

Our study focus on the Tapajós River basin (ca. $500000 \mathrm{~km}^{2}$ ), which is the fifth largest sub-basin of the Amazon River and covers $7 \%$ of the total Amazon basin (Pavanato et al., 2016). This basin includes 7 of the 41 municipalities where Brazilian Environmental authorities concentrate anti-deforestation efforts due to their high incidence of forest clearing (Bragança, 2015). In order to estimate the impacts of scale, we integrated to our study a sub-basin of the Tapajós, the Jamanxim River basin $\left(37400 \mathrm{~km}^{2}\right)$, and a pair of micro-catchments $\left(<1 \mathrm{~km}^{2}\right)$ with contrasting land uses (forest vs. pasture) located in the municipality of Novo Progresso, in the Brazilian state of Pará (Fig. 1). The climate in this area is humid tropical with a rainy season from November to May and a dry season that extends from June to October. Mean annual precipitation averages $1900 \mathrm{~mm}$.

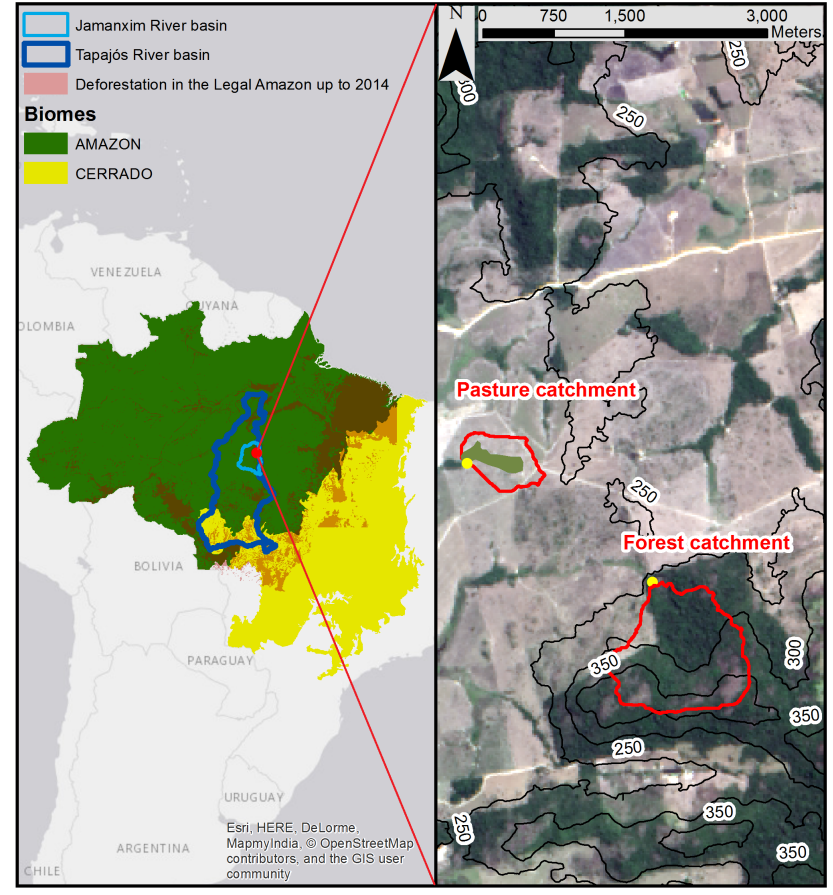

Figure 1. Area of study.

\section{Methods}

\subsection{Experimental micro-catchment study}

We compared the streamflow of the micro-catchments by using empirical data from field measurements from 2013 to 2014. At the catchment outlets, we installed rectangular weirs and a DS $5 \mathrm{X}$ multiparameter sonde (OTT, USA) to measure water level and to quantify streamflow. We quantified the runoff coefficient as the ratio of total streamflow to total precipitation, and the baseflow index as the ratio of total baseflow to total streamflow following Nóbrega et al. (2017). In these catchments, we also collected $1 \mathrm{~L}$ water samples during stormflow events for suspended sediment concentration (SSC) analysis following the method of ASTM (2000). More details on the catchments' characteristics and instrumentation setup can be found in Guzha et al. (2015).

\subsection{Jamanxim River basin modelling}

We simulated the hydrological behavior of the Jamanxin River basin using the SWAT eco-hydrological model (Arnold et al., 2012). For the setup, calibration and validation of SWAT, we used a gradual land-use change parameterization, field assessments, and available regional data, and then simulated a land-use change scenario in order to quantify the changes in the water balance components due to deforestation. The model parameterization, calibration and validation details can be found in Lamparter et al. (2016). The landuse change scenario used in this study (Fig. 2) suggests a 


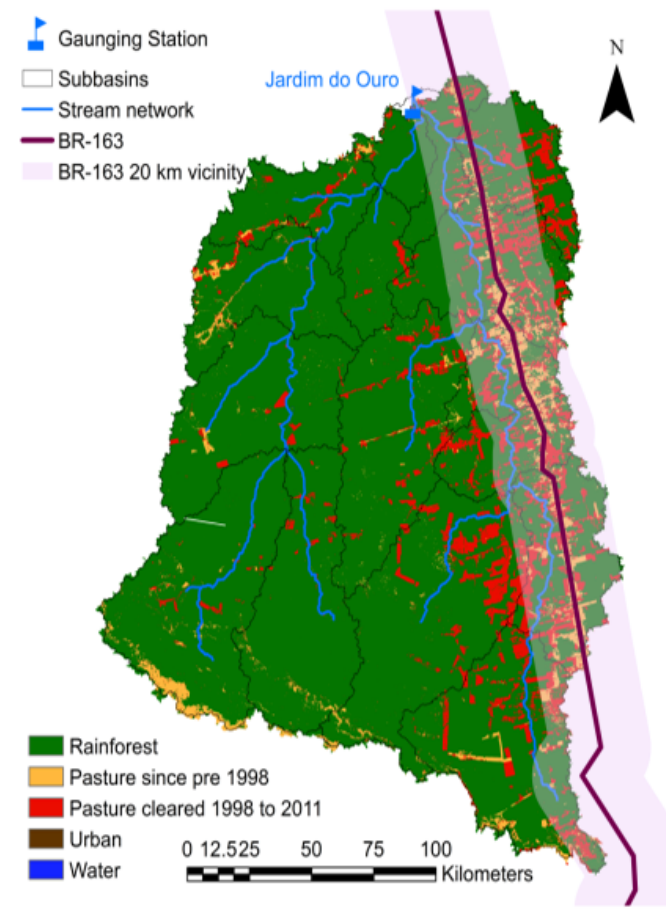

(a)

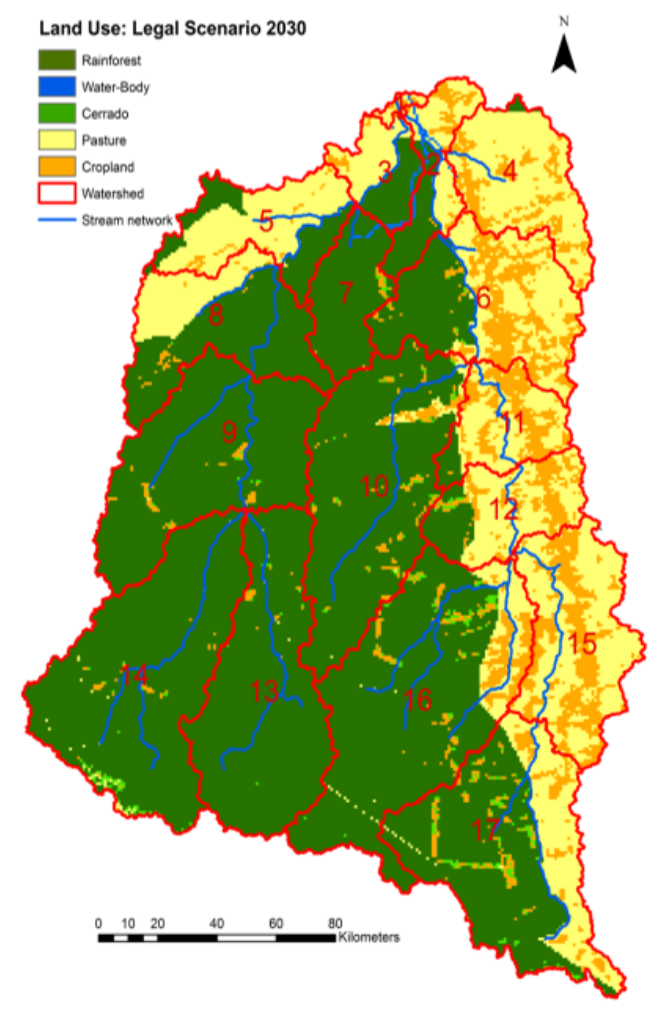

(b)

Figure 2. (a) Land-use distribution in 2011, and (b) Land-use scenario ( $22 \%$ of deforestation) for the year 2030 following a business as usual approach (Gollow et al., 2017).
Table 1. $Q$ results with SWAT for the land-use distribution and scenario.

\begin{tabular}{lcccc}
\hline $\begin{array}{l}P \\
(\mathrm{~mm})\end{array}$ & $\begin{array}{c}Q \\
(\mathrm{~mm})\end{array}$ & $\begin{array}{c}Q \\
\text { scenario } \\
(\mathrm{mm})\end{array}$ & $\begin{array}{c}\text { Qbase } \\
(\mathrm{mm})\end{array}$ & $\begin{array}{c}\text { Qbase } \\
\text { scenario } \\
(\mathrm{mm})\end{array}$ \\
\hline 1639 & 637 & 685 & 396 & 405 \\
\hline
\end{tabular}

rapid pasture expansion according the study of Gollnow et al. (2017).

\subsection{Tapajós River basin analysis}

We investigated trends in $Q$, sediments, and hydrochemistry and geochemistry, i.e. $\mathrm{pH}, \mathrm{DOC}, \mathrm{Mg}, \mathrm{K}, \mathrm{HCO}_{3}^{-}, \mathrm{Si}, \mathrm{NO}_{3}^{-}$ and $\mathrm{Ca}$, in the Tapajós River using available data from the HYBAM Observation Service (http://www.ore-hybam.org, station code 17730000). We used Mann-Kendall test for detecting either an upward or downward trend in the data series with a significance threshold set at .05 . The data were also used to quantify fluxes of nitrate and total dissolved carbon (DOC) using mean discharge and concentration in 5-year periods from 1996 to 2015 .

\section{Results and discussion}

Figure 3 shows the streamflow comparison between the two micro-catchments. The pasture catchment has a higher runoff coefficient (0.67) than the forest catchment (0.28). Baseflow indices were 0.76 and 0.88 for the pasture and forest catchments, respectively, showing a higher baseflow contribution in the forest catchment. At this scale, the SSC were also significantly higher during stormflows in the pasture (mean of $579.7 \mathrm{mg} \mathrm{L}^{-1}, n=37$ ) than in the forest catchment (mean of $81.8 \mathrm{mg} \mathrm{L}^{-1}, n=50$ ). The geometric mean and 75 th percentile for the SSC in the pasture and forest catchments were 47.2 and $26.1 \mathrm{mg} \mathrm{L}^{-1}$, and 886.0 and $147.8 \mathrm{mg} \mathrm{L}^{-1}$, respectively.

For the Jamanxim River basin, simulation results show a $2 \%$ increase in discharge $(Q)$ and a $5 \%$ reduction of baseflow contribution to total $Q$ after a $22 \%$ conversion of forest to pasture (Fig. 4 and Table 1). Our results are in accordance to Davidson et al. (2012); they state that even though basinscale impacts of land use may not yet surpass the magnitude of natural hydrological variability and biogeochemical cycles, there are some signs of a transition to a disturbancedominated regime, which include changes in the water cycle in the Southern and Eastern regions of the Amazon basin.

At the scale of the Tapajós River basin, however, trend analysis did not show any significant trend in discharge and sediment concentration. Hydrological changes due to landuse change are known to be primarily manifested at smaller scales. Therefore, we ascribe the absence of visible trend at 


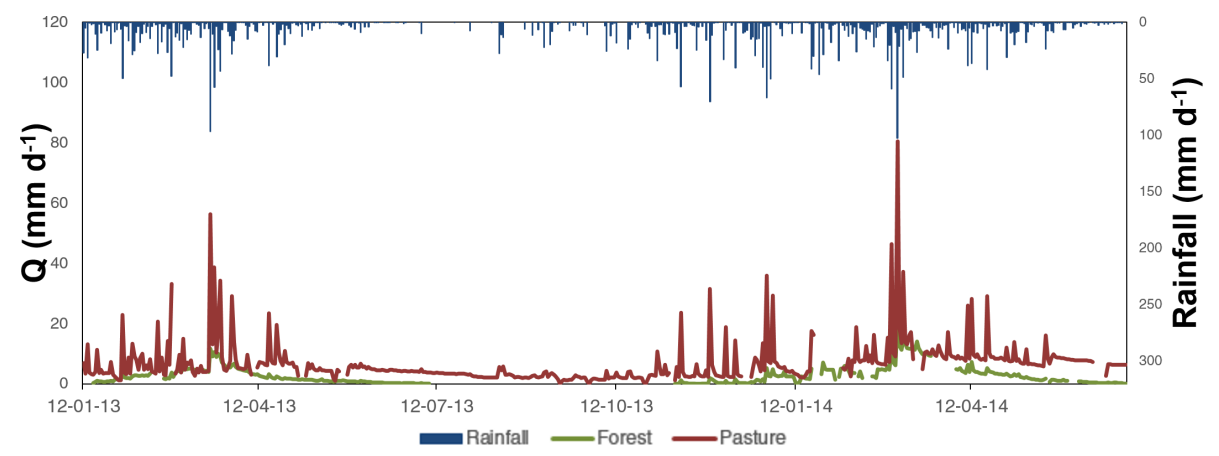

Figure 3. Streamflow and rainfall in the forest and pasture micro-catchments.

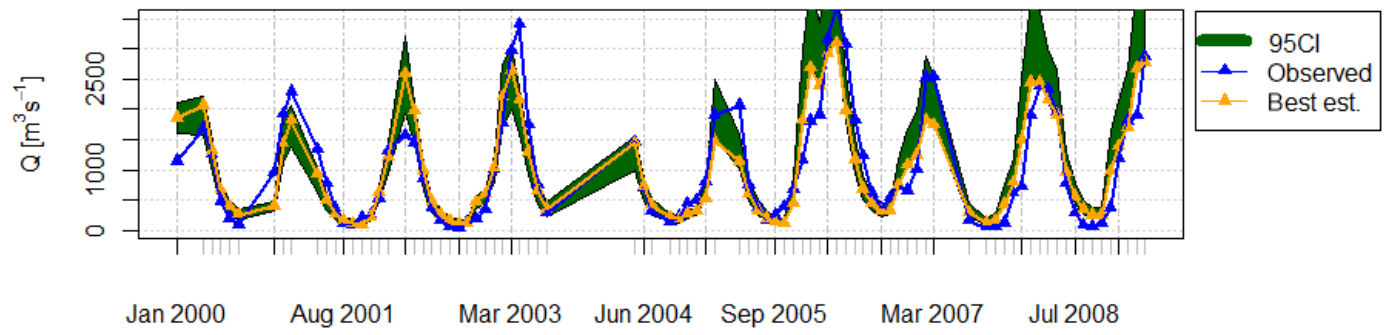

Figure 4. Calibration and validation with land-use update for the Jamanxim catchment.

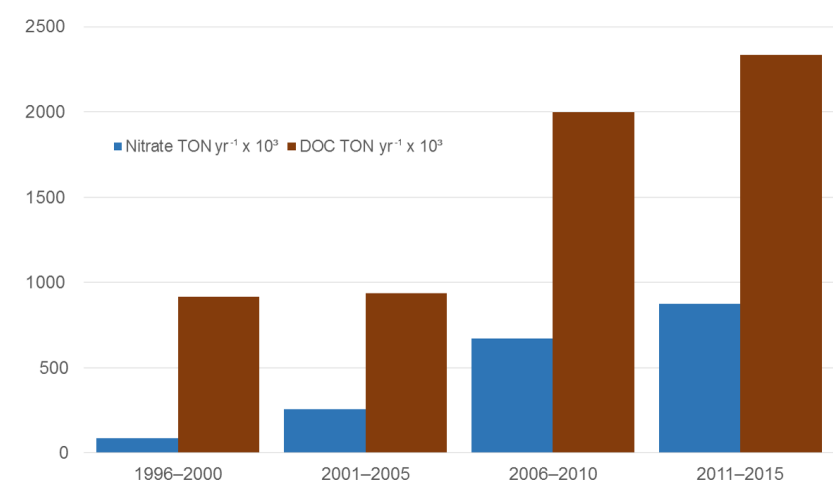

Figure 5. Nitrate and total dissolved carbon fluxes.

a large scale to the fact that most of the deforestation in the Tapajós River basin has occurred in its upper portion, which produces hydrological signatures that may be buffered along the river until its outlet. The analyses of the outflow fluxes over the last 20 years in the Tapajós River revealed upward trends in dissolved organic carbon and $\mathrm{NO}_{3}^{-}$, which have reached an up to 10-fold increase (Fig. 5).

\section{Conclusions}

Effects of deforestation on large rivers of the Amazon basin were relatively unknown due to the low degree of connection between large rivers and land uses in these basins (Neill et al., 2001). We were able to find changes in the Tapajós
River basin in river discharge, sediment concentration, and water quality across all studied scales. In this context, our study adds to an increasing body of literature showing that although the magnitude of anthropogenic impact has shown to be scale-dependent, some changes are detectable in both small and large rivers in the Amazon.

Data availability. The data used in this study for the microcatchments and Jamanxim are available from the Open Science Framework (https://doi.org/10.17605/OSF.IO/UCDE7) and the Spatial Data Infrastructure of the Carbiocial Project (http://gdi. carbiocial.de/). Time series used for the trend analysis are available from the HYBAM Observation Service (http://www.ore-hybam. org), and discharge data used to calibrate and validate the hydrological model are available from the HydroWeb platform of the National Water Agency of Brazil (http://hidroweb.ana.gov.br/, station code: 2650000).

Competing interests. The authors declare that they have no conflict of interest.

Special issue statement. This article is part of the special issue "Water quality and sediment transport issues in surface water". It is a result of the IAHS Scientific Assembly 2017, Port Elizabeth, South Africa, 10-14 July 2017. 
Acknowledgements. This research was feasible thanks to the support of the Bundesministerin für Bildung und Forschung (BMBF) through its grant to the CarBioCial project (grant number: 01LL0902A). The authors also acknowledge the data availability of HYBAM Observation Service and the National Water Agency of Brazil (ANA).

Edited by: Akhilendra B. Gupta

Reviewed by: Jagdish Kumar Bassin and one anonymous referee

\section{References}

Arnold, J. G., Moriasi, D. N., Gassman, P. W., Abbaspour, K. C., White, M. J., Srinivasan, R., Santhi, C., Harmel, R. D., van Griensven, A., Van Liew, M. W., Kannan, N., and Jha, M. K.: SWAT: Model Use, Calibration, and Validation, T. ASABE, 55, 1491-1508, https://doi.org/10.13031/2013.42256, 2012.

ASTM: Standard Test Methods for Determining Sediment Concentration in Water Samples: D3977-97, West Conshohocken, PA, 2000.

Bleich, M. E., Mortati, A. F., André, T., and Piedade, M. T. F.: Structural Dynamics of Pristine Headwater Streams from Southern Brazilian Amazon, River Res. Appl., 32, 473-482, https://doi.org/10.1002/rra.2875, 2016.

Bragança, A.: Prices, land use and deforestation: Evidence from the Tapajós basin, Rio de Janeiro, available at: http://www. inputbrasil.org (last access: 15 May 2017), 2015.

Davidson, E. A., de Araújo, A. C., Artaxo, P., Balch, J. K., Brown, I. F., Bustamante, M. M., Coe, M. T., DeFries, R. S., Keller, M., Longo, M., Munger, J. W., Schroeder, W., Soares-Filho, B. S., Souza, C. M., and Wofsy, S. C.: The Amazon basin in transition, Nature, 481, 321-328, https://doi.org/10.1038/nature10717, 2012.

Eshleman, K. N.: Hydrological Consequences of Land Use Change: A Review of the State-of-Science, in: Ecosystems and Land Use Change, edited by: Defries, R. S., Asner, G. P., and Houghton, R. A., American Geophysical Union, Washington, D.C., https://doi.org/10.1029/153GM03, 2004.

Fearnside, P. M.: Brazil's Amazonian forest carbon: the key to Southern Amazonia's significance for global climate, Reg. Environ. Chang., https://doi.org/10.1007/s10113-016-1007-2, in press, 2016.

Gollnow, F., Göpel, J., deBarros Viana Hissa, L., Schaldach, R., and Lakes, T.: Scenarios of land-use change in a deforestation corridor in the Brazilian Amazon: combining two scales of analysis, Reg. Environ. Chang., https://doi.org/10.1007/s10113-0171129-1, in press, 2017.

Guzha, A. C., Nobrega, R. L. B., Kovacs, K., Rebola-Lichtenberg, J., Amorim, R. S. S., and Gerold, G.: Characterizing rainfallrunoff signatures from micro-catchments with contrasting land cover characteristics in southern Amazonia, Hydrol. Process., 29, 508-521, https://doi.org/10.1002/hyp.10161, 2015.
Lamparter, G., Nobrega, R. L. B., Kovacs, K., Amorim, R. S., and Gerold, G.: Modelling hydrological impacts of agricultural expansion in two macro-catchments in Southern Amazonia, Brazil, Reg. Environ. Chang., https://doi.org/10.1007/s10113016-1015-2, in press, 2016.

Lima, L. S., Coe, M. T., Soares Filho, B. S., Cuadra, S. V., Dias, L. C. P., Costa, M. H., Lima, L. S. and Rodrigues, H. O.: Feedbacks between deforestation, climate, and hydrology in the Southwestern Amazon: Implications for the provision of ecosystem services, Landsc. Ecol., 29, 261-274, https://doi.org/10.1007/s10980-013-9962-1, 2014.

Neill, C., Deegan, L. A., Thomas, S. M., and Cerri, C. C.: Deforestation for pasture alters nitrogen and phosphorus in small Amazonian streams, Ecol. Appl., 11, 1817-1828, https://doi.org/10.1890/10510761(2001)011[1817:DFPANA]2.0.CO;2, 2001.

Nóbrega, R. L. B., Guzha, A. C., Torres, G. N., Kovacs, K., Lamparter, G., Amorim, R. S. S., Couto, E., and Gerold, G.: Effects of conversion of native cerrado vegetation to pasture on soil hydro-physical properties, evapotranspiration and streamflow on the Amazonian agricultural frontier, PLoS One, 12, e0179414, https://doi.org/10.1371/journal.pone.0179414, 2017.

Ometto, J. P., Aguiar, A. P. D., and Martinelli, L. A.: Amazon deforestation in Brazil: effects, drivers and challenges, Carbon Manage., 2, 575-585, https://doi.org/10.4155/cmt.11.48, 2011.

Pavanato, H. J., Melo-Santos, G., Lima, D. S., PortocarreroAya, M., Paschoalini, M., Mosquera, F., Trujillo, F., Meneses, R., Marmontel, M., and Maretti, C.: Risks of dam construction for South American river dolphins: A case study of the Tapajós River, Endanger. Species Res., 31, 47-60, https://doi.org/10.3354/esr00751, 2016.

Soares-Filho, B. S., Nepstad, D. C., Curran, L. M., Cerqueira, G. C., Garcia, R. A., Ramos, C. A., Voll, E., McDonald, A., Lefebvre, P., and Schlesinger, P.: Modelling conservation in the Amazon basin, Nature, 440, 520-523, https://doi.org/10.1038/nature04389, 2006.

Souza-Filho, P. W. M., de Souza, E. B., Silva Júnior, R. O., Nascimento, W. R., Versiani de Mendonça, B. R., Guimarães, J. T. F., Dall'Agnol, R., and Siqueira, J. O.: Four decades of land-cover, land-use and hydroclimatology changes in the Itacaiúnas River watershed, southeastern Amazon, J. Environ. Manage., 167, 175-184, https://doi.org/10.1016/j.jenvman.2015.11.039, 2016.

Thomas, S. M., Neill, C., Deegan, L. A., Krusche, A. V., Ballester, V. M., and Victoria, R. L.: Influences of land use and stream size on particulate and dissolved materials in a small Amazonian stream network, Biogeochemistry, 68, 135-151, https://doi.org/10.1023/B:BIOG.0000025734.66083.b7, 2004.

Vedovato, L. B., Fonseca, M. G., Arai, E., Anderson, L. O., and Aragão, L. E. O. C.: The extent of 2014 forest fragmentation in the Brazilian Amazon, Reg. Environ. Change, 16, 2485-2490, https://doi.org/10.1007/s10113-016-1067-3, 2016. 